\title{
Freshwater lichens of the Italian Alps : a review
}

\author{
J. Nascimbene*, P.L. Nimis \\ University of Trieste, Department of Biology, via Giorgieri 10 - 34100 Trieste, Italy
}

\begin{abstract}
The lichen flora of freshwater habitats in the Italian Alps is reviewed: 20 genera and 43 species are known, of which crustose lichens with sexual reproduction prevail. Freshwater lichen richness is highest near the treeline on siliceous substrata in exposed and well-lit sites. The importance of several ecological factors on freshwater lichen distribution and ecology is discussed.
\end{abstract}

Keywords : lichens, freshwater habitats, Italian Alps, flora, ecology, bioindication.

\section{Introduction}

Most lichens are bound to terrestrial habitats, but some species occur in aquatic environments, the best known of which are maritime, thriving in the intertidal zone periodically submerged by saltwater (e.g. Fletcher 1973a, 1973b, Seaward 1996). Only a few papers are devoted to freshwater lichens. According to Santesson (1939) and Aptroot \& Seaward (2003), freshwater lichens are amphibious organisms, most of them being submerged during only a part of the year. The photobiont is mostly a coccoid green alga or a cyanobacterium which can grow only near the surface of water, since it needs direct sunlight. The mycobiont is an ascomycete whose hyphae are covered by a hydrophobic layer that involves the photosynthetic partner (Ahmadjian1993, Honegger 1997, Nash 1996). Substrate stability is one of the main habitat features for lichen colonization, most species requiring stable and large stones whose surfaces are not subject to erosion (Thüs 2002). Thüs (2002) also provided a taxonomic monograph of the problematic group of "Hydroverrucaria" in Central Europe, with interesting notes on the ecology of freshwater lichens in general.

Freshwater lichens correspond to relatively few taxonomic groups. The freshwater lichen flora seems

\footnotetext{
* Corresponding author :

E-mail: junasc@libero.it
}

to be very homogeneous worldwide (Aptroot \& Seaward 2003), as exemplified by the distribution of Verrucaria margacea, a common species on siliceous rocks in the Alps, that includes Europe, North America, India and Australia (McCarthy 1995). Some recent works consider how these lichens can be used for biomonitoring (e.g. Gilbert 1996, Gilbert \& Giavarini 1997), but their indicator potential is not fully clear, and no standardised method is available for biomonitoring purposes. In spite of their limited number, freshwater lichens are often difficult to identify by non-specialists; therefore quantitative and semi-quantitative sampling methods are difficult to apply and a standard quantitative approach, similar to that used for evaluating epiphytic lichen diversity (Asta et al. 2002, Nimis et al. 2002), has yet to be developed.

Most of the remaining information on freshwater lichens is in the form of floristic surveys, such as those undertaken by Gilbert (1996) and Gilbert \& Giavarini (1997) in the British Isles, who adopted walk-over surveys in several watercourses, with visual estimations of lichen abundance, similar to that carried out by Pentecost (1977) on two mountain streams. In Central Europe, Molitor \& Diederich (1997) studied freshwater pyrenolichens of Luxembourg, and Mühlenhoff \& Büdel (1995) studied the aquatic bryophyte and lichen flora of six creeks in Germany. In the Alps (Switzerland), Keller \& Scheidegger (1994) studied by means of an ecological semi-quantitative approach the distribution of freshwater lichens relative to the annual in- 
undation period. Keller (2000) studied the lichen flora and vegetation of an Austrian watercourse by a detailed floristic survey in five different sites along the stream. Pereira et al. (1987) carried out a floristic survey in four sites along an immersion gradient in the Sierra Nevada (Spain).

No study was specifically devoted to the freshwater lichens of Italy. The available information on their occurrence in the country derives from several general floristic studies, mainly concerning the Alps (see Nimis 1993, 2003). This paper aims at providing an upto-date review of the freshwater lichen flora of the Italian Alps in order to establish a baseline for more intensive floristic and ecological studies on this interesting but often neglected guild of aquatic organisms.

\section{Data and methods}

Data on the distribution, ecology and rarity for each freshwater lichen species have been derived from ITALIC (Nimis 2003), the on-line information system on Italian lichens (Nimis \& Martellos 2002), by the appropriate query in the interface "special requirements for water". Three parameters were used: 1) Ecological indicator values: the ecological requirements of each species for $\mathrm{pH}$ of the substrate, humidity, light and eutrophication were defined by Nimis (2003) by indicator values ranging on a 5-class ordinal scale (see also Nimis \& Martellos 2002). The reliability of these indicators was demonstrated by Nimis \& Martellos (2001). 2) Phytoclimatic subdivision of Italian Alps: four Operational Geographic Units (OGUs) were used to explore the altitudinal distribution of freshwater lichens in the Italian Alps: (a) alpine belt: above the treeline, (b) subalpine belt: near the treeline, (c) montane belt (beech-belt), and (d) submediterranen belt (deciduous oak woods). 3) Commonness-rarity: evaluated for each OGUs by Nimis (2003) on the basis of three main criteria: (a) number of samples in the TSB lichen herbarium, (b) number of literature records, and (c) expert judgement. Nine classes were used, from absent to extremely common (see Nimis \& Martellos 2002). Comparative data on the freshwater lichens known from the Austrian Alps (species, altitudinal range and substrata) were taken from Hafellner \& Türk (2001). Nomenclature follows Nimis \& Martellos (2003).

\section{Results}

Forty-three freshwater lichens (including those of periodically inundated rocks) are known from the Italian Alps (Table 1), half of which are exclusive to this area. They make up only $2.4 \%$ of the alpine lichen flora of Italy. The best-known regions are also those with the highest total number of species, i.e. Trentino-Alto Adige (32 species), Piedmont (28 species) and Lombardy (26 species).

The species belong to 20 genera, the most species-rich being Verrucaria (19\% of the total), Aspicilia (10\%), Dermatocarpon (10\%) and Staurothele (10\%) (Tab.1). Crustose lichens with sexual reproduction comprise $80 \%$ of the total. Tab. 2 reports the percent occurrence of three main types of photobionts in the Italian flora, in the lichen flora of the Italian Alps, and among freshwater lichens of the Alps (data from Nimis, 2003). The photobiont is mostly a coccoid green alga $(72 \%)$, while cyanobacteria and trentepohlioid algae are less frequent ( $21 \%$ and $7 \%$, respectively).

The altitudinal distribution of freshwater lichen richness has a maximum in the subalpine belt near the treeline (93\% of the total), followed by the montane belt $(77 \%)$, the alpine belt $(63 \%)$ and the submediterranean belt ( $9 \%$ only). The subalpine belt also hosts the highest share of those species restricted to the Alps in Italy $(91 \%)$, followed by the alpine belt $(78 \%)$ and the montane belt $(60 \%)$. Thus, the altitudinal optimum of freshwater lichens seems to be in the subalpine belt near the treeline.

The range (2 to 3 ) of the indicator value for $\mathrm{pH}$ (Fig. 1 ) indicates that most species $(80 \%)$ colonise acid or subacid rocks. Light requirement values mostly range from 3 to 4 (Fig. 1), which indicates that freshwater lichens have an ecological optimum in well-lit habitats. No lichen of eutrophicated substrata is known, since most of species have a value of 1 for this factor (Fig. 1). As far as rarity is concerned, the species can be grouped into three categories (Table 1) with decreasing conservation priority: (I) extremely rare in all the phytoclimatic belts of Italy (3 species), (II) very rare in all the phytoclimatic belts of Italy (14 species), and (III) common in at least a phytoclimatic belt of Italy (the remaining species).

\section{Discussion}

Floristic richness - With more than 2300 species, the Alps are one of the lichenologically best known areas of the world. Nevertheless, floristic exploration is not homogeneous, and several areas need more intensive study. The Austrian checklist of Hafellner \& Türk (2001) lists 64 freshwater lichens, while only 43 species are known for the Italian Alps, a number which is likely to increase with further research. Nevertheless, 
Table 1. List of freshwater lichens in the Italian Alps. The main features of each species are reported: growth form, reproductive strategy, photobiont, occurrence within the phytoclimatic belts, exclusivity for the Alps, and rarity. Growth: $\mathrm{cr}=\mathrm{crustose}$; fol $=$ foliose; fru $=$ fruticose. Reproduction: $\mathrm{s}=$ mainly by sexual reproduction (ascospores); $\mathrm{i}=$ mainly by vegetative propagules (isidia). Photobiont: $\mathrm{ch}=$ green chloroccoid algae; $\operatorname{tr}=$ green algae belonging to the genus Trentepohlia $;$ cy = cyanobacteria. Phytoclimatic belt: alpine belt = above the treeline, subalpine $=$ near the treeline, montane $=$ beech-belt, and submediterranen belt $=$ deciduous oak woods. Excl. of the Alps: species that in Italy are restricted to the Alps. Rarity: I = extremely rare in all the phytoclimatic belts of Italy, II = very rare in all the belts, and III = common in at least one phytoclimatic belt of Italy.

\begin{tabular}{|c|c|c|c|c|c|c|c|c|c|}
\hline \multirow[b]{2}{*}{ Species } & \multirow[b]{2}{*}{$\begin{array}{l}\text { 妾 } \\
\text { o }\end{array}$} & \multirow[b]{2}{*}{ 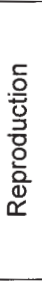 } & \multirow[b]{2}{*}{ 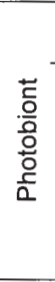 } & \multicolumn{4}{|c|}{$\begin{array}{c}\text { Phytoclimatic } \\
\text { belt }\end{array}$} & \multirow[b]{2}{*}{ 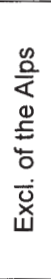 } & \multirow[b]{2}{*}{ 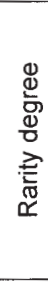 } \\
\hline & & & & 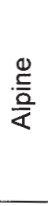 & 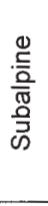 & 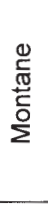 & 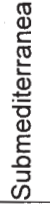 & & \\
\hline Aspicilia aquatica & $\mathrm{cr}$ & $\mathrm{s}$ & $\overline{\mathrm{ch}}$ & + & + & + & + & & III \\
\hline Aspicilia inornata & $\mathrm{cr}$ & s & $\mathrm{ch}$ & + & + & + & & & II \\
\hline Aspicilia laevata & $\mathrm{cr}$ & $\mathrm{s}$ & $\mathrm{ch}$ & & + & + & + & & III \\
\hline Aspicilia laevatoides & $\mathrm{cr}$ & $\mathrm{s}$ & $\mathrm{ch}$ & & + & + & & + & II \\
\hline Bacidina inundata & $\mathrm{cr}$ & $\mathrm{s}$ & $\mathrm{ch}$ & & + & + & & & III \\
\hline Dermatocarpon arnoldianum & fol & s & $\mathrm{ch}$ & + & + & + & & & III \\
\hline Dermatocarpon intestiniforme & fol & $\mathrm{s}$ & $\mathrm{ch}$ & + & + & + & & & III \\
\hline $\begin{array}{l}\text { Dermatocarpon luridum var. } \\
\text { luridum }\end{array}$ & fol & $\mathbf{s}$ & $\mathrm{ch}$ & + & + & + & & & I \\
\hline Dermatocarpon rivulorum & fol & s & $\mathrm{ch}$ & + & + & + & & + & III \\
\hline Ephebe lanata & fru & $\mathrm{s}$ & cy & + & + & + & & & III \\
\hline Ephebe perspinulosa & fru & $\mathrm{s}$ & cy & + & + & & & + & III \\
\hline Gyalidea roseola & $\mathrm{cr}$ & $\mathrm{s}$ & $\mathrm{ch}$ & & + & + & & + & I \\
\hline Hymenelia cyanocarpa & $\mathrm{cr}$ & $\mathrm{s}$ & $\mathrm{ch}$ & + & + & & & + & III \\
\hline Ionaspis lacustris & $\mathrm{cr}$ & $s$ & $\operatorname{tr}$ & + & + & + & & + & III \\
\hline Ionaspis odora & $\mathrm{cr}$ & $\mathrm{s}$ & $\operatorname{tr}$ & + & + & + & & + & III \\
\hline Koerberiella wimmeriana & $\mathrm{cr}$ & $\mathrm{i}$ & $\mathrm{ch}$ & + & + & & & + & II \\
\hline Leptogium magnussonii & fol & $\mathrm{i}$ & cy & & & + & + & + & II \\
\hline Lobothallia melanaspis & $\mathrm{cr}$ & $\mathrm{s}$ & ch & & + & + & & + & II \\
\hline Placynthium flabellosum & $\mathrm{cr}$ & $\mathrm{s}$ & cy & & + & + & & & III \\
\hline Placynthium rosulans & $\mathrm{cr}$ & s & cy & + & + & & & + & II \\
\hline Placynthium tantaleum & cr & $\mathrm{s}$ & cy & + & + & + & & + & II \\
\hline Polyblastia ardesiaca & $\mathrm{cr}$ & $\mathrm{s}$ & $\mathrm{ch}$ & + & + & & & + & III \\
\hline Polyblastia cruenta & $\mathrm{cr}$ & $\mathrm{s}$ & ch & + & + & & & + & III \\
\hline Porina guentheri & $\mathrm{cr}$ & $\mathrm{s}$ & $\operatorname{tr}$ & & + & + & & & $\mathrm{I}$ \\
\hline Porocyphus rehmicus & $\mathrm{cr}$ & $\mathrm{s}$ & cy & & & + & + & & II \\
\hline Pyrenopsis subareolata & cr & $\mathrm{s}$ & cy & & + & + & & & II \\
\hline Rhizocarpon lavatum & $\mathrm{cr}$ & $s$ & ch & + & + & + & & + & III \\
\hline Staurothele clopimoides & cr & $\mathrm{s}$ & $\mathrm{ch}$ & + & + & & & + & III \\
\hline Staurothele fissa & $\mathrm{cr}$ & s & $\mathrm{ch}$ & + & + & + & & & III \\
\hline Staurothele fuscocuprea & $\mathrm{cr}$ & $\mathrm{s}$ & $\mathrm{ch}$ & + & + & & & + & III \\
\hline Staurothele succedens & $\mathrm{cr}$ & $\mathrm{s}$ & $\mathrm{ch}$ & + & + & + & & + & III \\
\hline Thelidium aeneovinosum & $\mathrm{cr}$ & $\mathrm{s}$ & $\mathrm{ch}$ & + & + & & & + & III \\
\hline Thelidium pertusatii & $\mathrm{cr}$ & s & ch & + & & + & & + & II \\
\hline Verrucaria aethiobola & $\mathrm{cr}$ & $s$ & ch & & + & & & & III \\
\hline Verrucaria aquatilis & $\mathrm{cr}$ & s & $\mathrm{ch}$ & & + & + & & & III \\
\hline Verrucaria elaeomelaena & $\mathrm{cr}$ & s & ch & + & + & + & & & III \\
\hline Verrucaria hydrela & $\mathrm{cr}$ & $s$ & ch & & + & + & & & III \\
\hline Verrucaria latebrosa & $\mathrm{cr}$ & s & $\mathrm{ch}$ & & + & + & & & III \\
\hline Verrucaria margacea & $\mathrm{cr}$ & $\mathrm{s}$ & $\mathrm{ch}$ & + & + & + & & & III \\
\hline Verrucaria pachyderma & $\mathrm{cr}$ & s & $\operatorname{ch}$ & + & + & + & & + & II \\
\hline Verrucaria praetermissa & cr & $\mathrm{s}$ & $\mathrm{ch}$ & & + & + & & + & II \\
\hline Verrucaria rheitrophila & cr & s & $\mathrm{ch}$ & + & + & + & & + & II \\
\hline Zahlbrucknerella calcarea & $\mathrm{cr}$ & $s$ & cy & & + & + & & & II \\
\hline
\end{tabular}


Table 2. Percentage of the different photobionts in the Italian lichen flora (Italy), in the Italian alpine flora (It_Alps), and in the Freshwater lichens of the Italian Alps (Fr_It_Alps). Photobiont: $\mathrm{ch}=$ green chloroccoid algae (without Trentepohlia); $\mathrm{tr}=$ the genus Trentepohlia; cy = cyanobacteria.

\begin{tabular}{cccc}
\hline Photobiont & Italy & It_Alps & Frw_It_Alps \\
\hline Ch & 82 & 82.7 & 72 \\
Cy & 9 & 10 & 21 \\
Tr & 9 & 7.3 & 7 \\
\hline
\end{tabular}

these 43 species constitute $81 \%$ of all freshwater lichens known from Italy, indicating the superiority of alpine over Mediterranean environments for such species. The most probable reason for this is the different climatic pattern of the two areas, most Mediterranean creeks being dry during summer; nevertheless, Nimis \& Poelt (1987) described a new species of freshwater lichen (Aspicilia hydrocharis) from the bottom of a basaltic creek dry during summer in northern Sardinia which is evidently able to tolerate both full submersion during winter and extreme drought during summer. However, freshwater lichens have been poorly studied in the high Mediterranean mountains and it is possible that further interesting species could be found there.

Photobionts - Does the aquatic environment exert a selective pressure in favour of certain photobionts? The share of species with chlorococcoid algae is al-

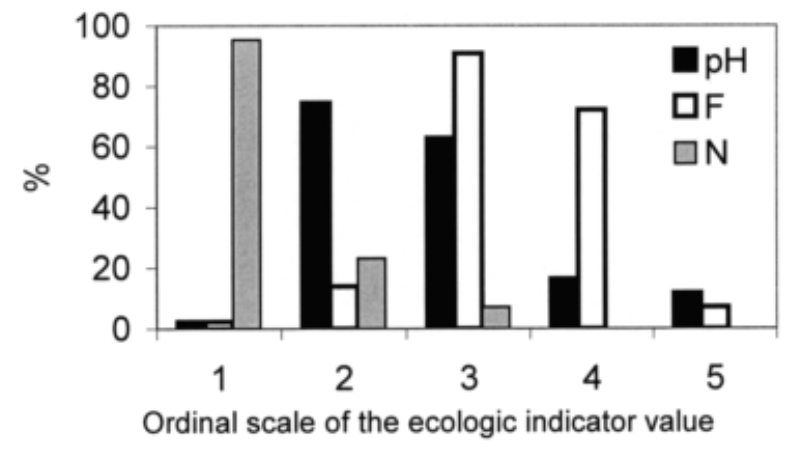

Fig. 1. Ecological indicators values. $\mathrm{pH}=\mathrm{pH}$ of the substratum $(1=$ on very acid substrata; $2=$ on acid substrata; $3=$ on subacid to subneutral substrata; $4=$ on slightly basic substrata; $5=$ on basic substrata). F = Solar irradiation $(1=$ in very shaded situations; 2 $=$ in shaded situations; $3=$ in sites with plenty of diffuse light but scarce direct solar irradiation; 4 = in sun-exposed sites, but avoiding extreme solar irradiation; $5=$ in sites with very high direct solar irradiation. $\mathrm{N}=$ Eutrophication $(1=$ no eutrophication; $2=$ very weak eutrophication; 3 = weak eutrophication; 4 = rather high eutrophication; 5 = very high eutrophication. most the same in all cases, while lichens with cyanobacteria constitute ca. $21 \%$ of freshwater species against 8-9 \% of the total floras. Cyanolichens need liquid water for photosynthesis (Nash 1996) and usually colonise periodically inundated surfaces, or epiphytic mosses with a high water retention capacity. Periodically submerged stones represent an excellent habitat for this group of lichens. Lichens in symbiosis with algae of the genus Trentepohlia are rare in the alpine environment (Martellos et al. 2004) and mostly confined to sheltered and humid habitats. In freshwater habitats, a few Trentepohlioid species of Ionaspis and Porina can be found on sheltered surfaces with slow water flow.

Altitudinal distribution - The altitudinal distribution of freshwater lichens in the Italian Alps shows a maximum of richness in the subalpine belt and a minimum in the submediterranean belt. In Austria the distribution is similar, which suggest that this is the general trend throughout the Alps. Furthermore, Thüs et al. (2004) reached similar results in Central Europe in their survey of amphibious and submerged lichens from low mountains to subalpine areas. They related the altitudinal distribution with studies on photobionts, concluding that in subalpine areas more taxa of photobionts are available for submerged lichens, because of higher resistance to submersion due to low temperatures increasing the gas-holding capacity of water. On the contrary, at low altitudes with higher water temperatures, $\mathrm{CO}_{2}$ availability may be a limiting factor for submerged lichens. Freshwater lichen diversity could follow a temperature-dependent gradient of resistance of photobionts to submersion. Other environmental factors, however, should be taken into account for explaining the higher richness of freshwater lichens in upland areas, such as substrate stability, phanerogamic vegetation, light availability, silting and eutrophication. In particular, silting can severely limit lichen growth, both because of its interference with light penetration and because of its mechanical effect when covering the thalli (Thüs 2002). In the alpine belt, increased instability of riverbeds could represent a strong limiting factor for freshwater lichens. Furthermore, melt-water from glaciers is rich in particles, muddy, and very turbulent. In the subalpine belt, plenty of light is available, since only low shrubs and scattered trees are present, the slopes are less steep, riverbed stones are more stable, and waters are less dense in suspended particles, which allows a deeper penetration of light into water. In the montane belt, rivers flow through forests where light availability may not be sufficient for freshwater lichens and mosses generally 
predominate (Thüs 2002). The submediterranean belt is the most disturbed, with water pollutants, eutrophication, human activities affecting freshwater lichens. Thüs (2002) suggested that the decrease of lichens might be not due to eutrophication itself, but to silting and competition with free-living algae. However, it should be noted that eutrophication and silting are often related.

Substrates - Both in the Italian Alps and in Austria silicicolous species are prevalent, reaching $80 \%$ and $83 \%$ of the totals, respectively. Are siliceous rocks a more suitable substrate for freshwater lichens? Were calcicolous lichens overlooked? At site level, siliceous rocks represent a stable substrate due to their high resistance to erosion and their wrinkled surfaces harbour lichen diaspores, enhancing thallus development. On the contrary, calcareous rocks suffer both mechanical and chemical erosion; thalli are often thin and incomplete, and only a few resistant species can survive. At landscape level, calcareous areas of the Alps have a poorly developed hydrographic net, due to karst phenomena, leading to a reduction in habitats for freshwater lichens. Nevertheless, more intensive research could increase the number of freshwater lichens known from calcareous rocks. In the Britain, Gilbert (1996) found a surprisingly high number of freshwater species, 30 of which were calcicolous.

Reproductive strategies - Sexual reproduction is the prevalent strategy for dispersal among freshwater lichens of the Italian Alps. As suggested by Aptroot \& Seaward (2003), the amphibious life-style explains the fact that freshwater lichen dispersal can be long distance, as indicated by the high similarity of freshwater lichen floras worldwide. Pyrenolichens are the most representative group, since perithecia are more resistant to water-flow than apothecia, as they offer an efficient protection to the fertile hymenium inside their subspherical and closed structure (Aptroot \& Seaward 2003). Only a few species, such as Koerberiella wimmeriana growing in the splash zone, form lichenised structures (isidia or soredia) for vegetative dispersal; these are probably damaged by the abrasion of water flow.

Conservation - The conservation status of several freshwater lichens in the Italian Alps should be interpreted mainly in the light of our limited knowledge of these habitats in Italy. The species restricted to the Alps may represent the main focus for conservation priorities (Martellos et al. 2004), but more data are needed to reach any realistic conclusions about their status. The main threats are posed by hydroelectric de- velopments which involve water abstraction. Traditional and touristic uses of freshwaters can also lead to a reduction of freshwater lichen diversity if silting and nitrate-phosphate levels are increased (Thüs 2002). A generalized habitat protection is a prudent approach that can compensate for poor taxonomic knowledge, especially in protected areas such as Natural Parks and Natura 2000 sites, with particular care devoted to springs, due to their structural vulnerability. Gilbert (1996) pointed out that springs are the optimal habitat for several species of Verrucaria.

Bioindication - The overall similarity of freshwater lichen floras over wide areas was pointed by Aptroot $\&$ Seaward (2003) as the main reason for using these organisms in biomonitoring studies. Thüs (2002) discussed their potential for bioindication in respect of silting, incidence of saprobic organisms, eutrophication, water acidity, water levels and substrate stability. He underlined the risks in data interpretation due to the interference of different ecological factors affecting freshwater lichens, pointing out, for example, that any conclusions on water acidity is impossible if no stable substrata are present, and that silting may be considered a dominant factor when other important parameters are near their optimum. Freshwater lichens seem to be mono-responsive indicators whose applicability is very limited. Their potential as indicators needs further investigation in terms of sampling strategies to obtain reproducible results and homogeneous interpretative scales.

\section{Conclusions}

Although the Italian Alps are relatively well-known from the lichenological point of view, a series of floristic surveys specifically devoted to freshwater habitats is likely to increase the hitherto known number of species, especially in the least explored regions, such as Friuli (E Alps) and Val d'Aosta (W Alps). Such surveys should be best focused on the subalpine belt near the treeline, which constitutes the altitudinal optimum for freshwater species. Siliceous rocks are likely to host the highest number of taxa, but an investigation of the poorly known calcareous substrata is recommended as well. Springs, in particular, are likely to merit attention, since they seem to host a relatively high number of species, and to be particularly vulnerable. Freshwater habitats include a broad range of different ecological niches: future studies would profit from a careful planning of sampling strategies in order to capture the maximum of ecological diversity. In particu- 
lar, for several mountain streams of the Italian Alps, chemical-physical and biological data related to water quality are abundantly available (e.g. Boscaini et al. 2004, Lencioni et al. 2002). Floristic-ecological surveys carried out along such streams could permit to directly relate the occurrence of freshwater species to the physical and biological parameters of their habitats.

\section{Acknowledgments}

The work is part of the CRENODAT Project, a multidisciplinary study of the springs of Trento Province, coordinated by Museo Tridentino di Scienze Naturali (Trento). We are grateful to Prof. M.R.D. Seaward for his precious suggestions and to an anonymous referee for important critical remarks.

\section{References}

Ahmadjian V. 1993. - The Lichen Symbiosis. John Wiley, New York. ANPA. 2001. - I.B.L. Indice di Biodiversità Lichenica. ANPA, Manuali e Linee Guida, 2, Roma, 85 pp.

Aptroot A. \& Seaward M.R.D. 2003. - Freshwater lichens. Fungal Diversity Research Series 10, 101-110.

Asta J., Erhardt W., Ferretti M., Fornasier F., Kirschbaum U., Nimis P.L., Purvis O.W., Pirintsos S., Scheidegger C., Van Haluwyn C. $\&$ Wirth V. 2002. - Mapping lichen diversity as an indicator of environmental quality. Pages 273-280 in Monitoring with lichens Monitoring lichens. Nimis P.L., Scheidegger C. \& Wolseley P.A. (eds.). Kluwer, NATO Science Series, Earth and Envir. Ser. 7.

Boscaini A., Corradini F., Lencioni V. \& Maiolini B. 2004. - Caratterizzazione morfologica e chimico-fisica di un sistema idrografico alpino (Parco Nazionale dello Stelvio, Trentino). Studi Trentini di Scienze Naturali. Acta Biol., 80, 43-49.

Fletcher A. 1973a. - The ecology of marine (littoral) lichens on some rocky shores of Anglesey. Lichenologist, 5, 368-400.

Fletcher A. 1973b. - The ecology of marine (supralittoral) lichens on some rocky shores of Anglesey. Lichenologist, 5, 401-422.

Gilbert O.L. 1996. - The lichen vegetation of chalk and limestone steams in Britain. Lichenologist, 28, 145-159.

Gilbert. O.L. \& Giavarini V. J. 1997. - The lichen vegetation of acid watercourses in England. Lichenologist, 29, 347-367.

Hafellner J. \& Türk R. 2001. - Die lichenisierten Pilze Österreichs eine Checkliste der bisher nachgewiesenen Arten mit Verbreitungsangaben. Stapfia, 76, 1-167.

Honegger R. 1997. - Metabolic interactions at the mycobiont-photobiont interface in lichens. Pages 209-221 in The Mycota V, Part A, Plant relationships. Carroll G.C. \& Tudzynski P. (eds.). SpringerVerlag, Berlin.

Keller C. 2000. - Die Wasserflechten der Teigitsch zwischen der Langmannsperre und dem Kraftwerk Arnstein (Steiermark, Österreich). Herzogia, 14, 49-58
Keller C. \& Scheidegger C. 1994. - Zur Verbreitung von Wasserflechten in Abhängigkeit zur jährlichen Überflutungsdauer im Flüelatal (Schweiz, Kanton Graubünden). Herzogia, 10, 99-114.

Lencioni V., Maiolini B., Zuccati S. \& Corradini F. 2002. - Zoobenthos drift in two high mountain streams in the de la Mare glacial system (Stelvio National Park, Trentino, Italy). Studi Trentini di Scienze Naturali - Acta Biol., 78, 49-57.

Martellos S., Nascimbene J. \& Nimis P.L. 2004. - I licheni delle Alpi: biodiversità e conservazione. Report APAT 45/2004, Roma, 176-186.

McCarthy P.M. 1995. - Aquatic species of Verrucaria in eastern Australia. Lichenologist, 27, 105-126.

Molitor F. \& Diederich P. 1997. - Les pyrenolichens aquatiques du Luxembourg et leur champignons lichénicoles. Bull. Soc. Nat. Luxemb., 98, 69-92.

Mühlenhoff D. \& Büdel B. 1995. - Vergleich der Wassermoos- und Wasserflechtenvegetation zweier Bachtypen (Waldbäche/Wiesenbäche) im Spessart. Nova Hedwigia, 61, 525-545.

Nash III T.H. 1996. Lichen Biology. Cambridge University Press, Cambridge.

Nimis P.L. \& Poelt J. 1987. - The lichens and lichenicolous fungi of Sardinia (Italy). Studia Geobot., 7, suppl. 1. 1-269.

Nimis P.L. 2003. - Checklist of the Lichens of Italy 3.0. University of Trieste, Dept. of Biology, IN3.0/2 (http://dbiodbs.univ.trieste.it/).

Nimis P.L. \& Martellos S. 2001. - Testing the predictivity of ecological indicator values. A comparison of real and "virtual" relevés of lichen vegetation. Plant Ecol., 157, 165-172.

Nimis P.L. \& Martellos S. 2002. - ITALIC, the information system on Italian lichens. Biblioth. Lichenol., 82, 271-283.

Nimis P.L., Scheidegger C., Wolseley P.A. (eds.). 2002. - Monitoring with lichens - Monitoring lichens. Kluwer, NATO Science Series, Earth and Envir. Ser. 7, 408 pp.

Nimis P.L. \& Martellos S. 2003. - A second checklist of the lichens of Italy with a thesaurus of synonyms. Museo Regionale di Scienze Naturali, Saint-Pierre, Aosta, Monografie, 4, 192 pp.

Pentecost A. 1977. - A comparison of the lichens of two mountain streams in Gwynedd. Lichenologist, 9, 107-111.

Pereira I.A., Casares M. \& Llimona X. 1987. - Aportacion al conocimiento de los liquenes hidrophilos de Sierra Nevada (Granada, S de España). Cryptogam. Bryol. Lichenol., 8, 263-273.

Santesson R. 1939. - Amphibious pyrenolichens I. Arkiv Botanik, 29, 1-67.

Seaward M.R.D. 1996. - Lichens and the environment. Pages 293320 in A century of mycology B.C. Sutton (ed.). Cambridge University Press, Cambridge.

Thüs H. 2002. - Taxonomie, Verbreitung ond Ökologie silicicoler Subwasserflechten im ausseralpinen Mitteleuropa. Bibl. Lichenol., 83, 1-214.

Thüs H., Helms G., Friedl T. \& Budel B. 2004. - High diversity of sub-alpine aquatic lichens - is it determined by the submersion resistance of lichen photobionts? Book of Abstracts, 5th IAL Symposium, Tartu, 63 . 